\title{
The rules that govern movable and immovable assets in international law
}

\author{
Abasat Pur MOHAMMAD ${ }^{1}$, Alireza HARAJ ${ }^{2}$ \\ ${ }^{1}$ Associate Professor, Maraghe branch, Islamic Azad University, Maraghe, Iran \\ ${ }^{2} \mathrm{PhD}$ Student, Faculty of private law, Maraghe branch, Islamic Azad University, Maraghe, \\ Iran
}

\begin{abstract}
Human societies have long formed coincided with legislation.With the advent of multiple communities, different legal systems took shape gradually expanding communication and interaction of different nations together and passenger transport goods into the territory limits of a legal system, legal system, gradually "cause the laws have been violated. In today's world with the development of high-speed transport, unprecedented expansion of international trade, cross-border travel increase and more and more evident importance of conflict of laws Ast.hm now many international conventions, each of them are associated with this science. Topics and issues related to immovable property right material conflict of laws is an important issue that despite the lack of resources trying to collect and draw conclusions from them. One of the categories of communication that will be discussed in private international law, the issue of "property", which is basically the law of the country where the property is located there, as the law is concerned. Therefore, to determine the location of the property is important for determining the applicable law. construction. Material possessions-existent property and material base; the non-material property that do not exist and the material base of society, but their existence and validity of the law it is known. it may be some differences in terms of the law governing the financing of movable or immovable it is different.
\end{abstract}

Keywords: conflict, immovable assets, material possessions-existent, society.

\section{Introduction}

since in some ways there are differences between them, it is necessary to present classified material alcohol movable and immovable deal in Iran's domestic law. Article 11 of the Civil Code property is divided into two kinds of movable and immovable and immovable property in Article 12 of the same Act's definition of "immovable property that can not be transported from one place to the other, whether or location to another is possible without having to enter it comes destruction is real. "

Realities suggest that the vast world, globalization is a challenge involved. Fear of globalization on the one hand and possibilities arising from the process of globalization on the other hand, the decision has been associated with uncertainty and greater accuracy. The 
capital, the engine of economic growth and development in all theories of economic growth is considered.

Hence, attract sufficient capital to finance economic projects, including the most important economic decision-makers in any community concerns (Farzin et al., 2011). So today, with the development of financial markets in the world and economic globalization, countries inevitably to attract foreign capital and competition are to attract it.

Economic development requires investment in various sectors and activities.

No investment in infrastructure and superstructure schemes can not be expected to develop production, employment and economic welfare. Today, many countries have a strong tendency to attract foreign capital (Shakeri and Solomon, 2005). Significant impact on foreign direct investment in developing countries, indicated the role of this form of investment is in their economic boom (Jalaei and Pvrfrd Sabbagh, 2009). Today, foreign investment as one of the most important sources of financing and technology transfer in developing countries is discussed. Because foreign investors over domestic investors competitive advantages such as access to adequate information, management skills, technology is advanced and reliable financial resources (Hi et al., 2011).

As well as automotive manufacturing companies that the members of this research is important. foreign and international has contributed to improve the ranking of countries in the field and evaluation of the efforts of different countries that has been of interest to all authorities (Fathy, 2013). Hence, this study is to identify the major obstacles to foreign investment in the automotive industry, according to the index of business.

\section{Materials and methods}

Questionnaires can be distributed among groups or individuals own shop to fill it. Personal interviews can be face to face with the interviewer and the interviewee advance by phone. The use of questionnaires or interviews and how to do it, largely depends on the research design.

Questionnaires and interviews. Both methods are based on a series of questions. The questions are written in the questionnaire and the response in writing is provided in writing its response. In the interview, the interviewer questions written on index interview asks and answers the note or recording.

Based on research, data collection can be divided into two categories: descriptive study and experimental research - Non-descriptive study consisted of 5 categories: descriptive, correlational, action research, case studies is divided into two categories: semi-experimental study, all the testing and research.

The method of this study is based on data collection descriptive. In this study was to evaluate the characteristics of a community distribution and management of this type is more research. In the survey, population parameters were evaluated. The researchers selected a sample that is representative of the community to assess the variables studied. This survey is 
divided into three categories. Cross: gathering data on one or more attributes at a particular time. Longitudinal method on longitudinal survey data collected over time the relationship between the variables over time to be measured: To investigate the views of the experts on a particular topic can be made using this technique. The study is cross-sectional survey research are placed in the category.

The study because it has not been manipulated variable and there is no laboratory conditions, the type of descriptive studies (nonrandomized) is. Descriptive research includes a set of methods that aim to describe the condition of the phenomenon studied. The purpose of the present study are the identification of existing conditions

\section{Discussion}

Although for the first time, old school Italian 13th and 14th century, divided into categories of communication with persons or property, failed to find the law governing the communication category of property. But, now that the property is subject to any law, lawyers have offered different theories on Private International Law. In fact, property ownership laws have been enacted to protect the interests of individuals, but also to national interests has been provided. The laws of property, is that political power be supported countries. Due to this fact, social purpose property laws, the most common side agrees

Iran on private international law, the legal regime governing property owned by foreign entities, Articles 8 and 966 civil law prescribed that according to the internal rules of conflict resolution, the rule location of your property will follow.

In the meantime, division of property, material and immaterial principle of the universality and integrity of those rights is no exception.

Investment in the automotive industry by providing the necessary guarantee of improving the quality products and services related to investors.

In order to improve the approach, some interaction with insurance companies can be made on the conclusion of agreements with foreign investors to maintain their capital and financial value and also automotive companies, in the discussion on capital and basic infrastructures, including movable and immovable property, machinery, facilities and so on, can provide required and credible safeguards for foreign investors. it can be seen that in the first place, negative attitude towards the main obstacle to foreign investment is the main obstacle for attracting foreign investment in the automotive industry in Iran. Thus, due to the existence of negative attitude among investors to invest in the automotive industry, it is need to remove these and a good solution that can be provided in this regard is advertising and promoting a positive approach and this is not possible without the help of expert manpower and infrastructure, and industry updates and keeping up with international industry as well as providing extensive and excellent after-sales service and customer-orientation in order to create a positive attitude and improve the outlook for foreign Now.. With these explanations, automotive companies in order to attract foreign investment, can increase quality and efficiency of industrial goods and in this way provide better market in the national and 
international levels for themselves.

It can be said that creating economic stability and transparency of accounts and financial statements and creating financing and financial guarantees to foreign investors, reduced investment risk or agreement in investment as stair-step and profits and payments and gaining trust in accounts payable to investors in due course in the realization of these things ultimately could lead to risk reduction.

In the second place, investor's financial security is one of main obstacles to attract foreign investment in the automotive industry in Iran. Given the changes and transformations, and unpredictable conditions for what occurs in industries in Iran, it can be said that this problem can be solved through improvement and stability of economic and political relationships of Iran with other countries; that in the course of realization of these, economic and political stability at national and international level between the authorities and society, conditional on performance obligations and preserving the value of money by the government and facilitating international relations are needed.

In relation to high investment risk and complex administrative process that received close scores in the regression analysis, but in correlation test, it was found that there is significant relationship between high investment risk and investment barriers, but there is no significant relationship between complex administrative process and barriers.

This is while the risk in investment in Iran's automobile industry in Iran to foreign investors could continue and seem important because this risk is associated with other important obstacles.

According to the analysis of the information obtained, it is seen that the predictor variables of barriers to foreign investment in Iran's automotive industry are: negative mentality, lack of adequate financial security for investor, inappropriate development of financial market and high risk of investment and it is also seen that the complex administrative process is not considered as one of the barriers to investment and by improvements and facilities provided so far, the view that performing formal administrative procedures for doing this is difficult and demanding is vanished and the predictive score of this variable was the lowest score.

About the third variable, which is inappropriate development of financial market in Iran's automobile industry and the participants consider it as the third place of obstacles, we can say lack of optimal and proper development of financial market will cause facing problem not only in attracting foreign investment, but also in many other fields that the main reasons can be exclusivity of automotive industry and few number of companies having the power of industry that causes less attention to development and diversification in this market that in concrete steps are taken order to solve this problem, it is recommended that variety of products and services and being align with updated science and technology and attracting customers and customer satisfaction for developing the market. In relation to the complex regulation that was in last place in the ranking of barriers to foreign investment, there is no significant relationship between these two and given that in recent years with improvement of e-government and performing a lot of work steps and process as digital in virtual world, from the perspective of participants, conditions and administrative procedures are improved and are not considered a great obstacle, so they can removed from foreign investment barriers; that 
the fifth hypothesis is rejected and stated as ineffective.

\section{Conclusion}

Investment in the automotive industry by providing the necessary guarantee of improving the quality products and services related to investors.

In order to improve the approach, some interaction with insurance companies can be made on the conclusion of agreements with foreign investors to maintain their capital and financial value and also automotive companies, in the discussion on capital and basic infrastructures, including movable and immovable property, machinery, facilities and so on, can provide required and credible safeguards for foreign investors. it can be seen that in the first place, negative attitude towards the main obstacle to foreign investment is the main obstacle for attracting foreign investment in the automotive industry in Iran. Thus, due to the existence of negative attitude among investors to invest in the automotive industry, it is need to remove these and a good solution that can be provided in this regard is advertising and promoting a positive approach and this is not possible without the help of expert manpower and infrastructure, and industry updates and keeping up with international industry as well as providing extensive and excellent after-sales service and customer-orientation in order to create a positive attitude and improve the outlook for foreign Now. With these explanations, automotive companies in order to attract foreign investment, can increase quality and efficiency of industrial goods and in this way provide better market in the national and international levels for themselves.

It can be said that creating economic stability and transparency of accounts and financial statements and creating financing and financial guarantees to foreign investors, reduced investment risk or agreement in investment as stair-step and profits and payments and gaining trust in accounts payable to investors in due course in the realization of these things ultimately could lead to risk reduction.

In the second place, investor's financial security is one of main obstacles to attract foreign investment in the automotive industry in Iran. Given the changes and transformations, and unpredictable conditions for what occurs in industries in Iran, it can be said that this problem can be solved through improvement and stability of economic and political relationships of Iran with other countries; that in the course of realization of these, economic and political stability at national and international level between the authorities and society, conditional on performance obligations and preserving the value of money by the government and facilitating international relations are needed.

In relation to high investment risk and complex administrative process that received close scores in the regression analysis, but in correlation test, it was found that there is significant relationship between high investment risk and investment barriers, but there is no significant relationship between complex administrative process and barriers.

This is while the risk in investment in Iran's automobile industry in Iran to foreign investors could continue and seem important because this risk is associated with other important obstacles. 
According to the analysis of the information obtained, it is seen that the predictor variables of barriers to foreign investment in Iran's automotive industry are: negative mentality, lack of adequate financial security for investor, inappropriate development of financial market and high risk of investment and it is also seen that the complex administrative process is not considered as one of the barriers to investment and by improvements and facilities provided so far, the view that performing formal administrative procedures for doing this is difficult and demanding is vanished and the predictive score of this variable was the lowest score.

About the third variable, which is inappropriate development of financial market in Iran's automobile industry and the participants consider it as the third place of obstacles, we can say lack of optimal and proper development of financial market will cause facing problem not only in attracting foreign investment, but also in many other fields that the main reasons can be exclusivity of automotive industry and few number of companies having the power of industry that causes less attention to development and diversification in this market that in concrete steps are taken order to solve this problem, it is recommended that variety of products and services and being align with updated science and technology and attracting customers and customer satisfaction for developing the market. In relation to the complex regulation that was in last place in the ranking of barriers to foreign investment, there is no significant relationship between these two and given that in recent years with improvement of e-government and performing a lot of work steps and process as digital in virtual world, from the perspective of participants, conditions and administrative procedures are improved and are not considered a great obstacle, so they can removed from foreign investment barriers; that the fifth hypothesis is rejected and stated as ineffective.

\section{REFERENCES}

[1] Partoy Shafagh, M, strategies to attract foreign investment in Iran, Islamic Azad University of Tehran, Tehran, 1382, p.168.

[2] Tarverdizadeh, Roya, investigating barriers for export of passenger automobiles in companies of Iran Khodro and Saipa in Iran, Islamic Azad University, Central Tehran Branch, Tehran, 1380, 168 pages.

[3] Jalaii, S.M. Sabbagh pourfard, M., Investigating the effect of FDI on economic growth through financial markets, economic research journal, summer 1388; 9 (2 (33)): 171-188.

[4] Jefreh, Reza, Investigating the factors affecting the attraction of foreign investment in provinces, Bushehr, the Management and Planning Organization of Bushehr, 2007, 53 pages.

[5] Sarfraz, Leila, economic reforms in foreign direct investment in Iran, political economic information, numbers 193-194, November 1382, pp. 207-200.

[6] Sarmad, Zohreh. et al. (1378). Research methods in the behavioral sciences, Aghah Publications, Tehran, Second Edition 
[7] Salami, Reza, Ramezani, Hadi, Sadighi Gariz, Sima., Jamali., Ahmad., selecting the appropriate method of foreign investment by using the techniques of multi-criteria decision-making in the Islamic Republic of Iran's oil refining industry, Industrial Management Studies Winter 1390; 9 (23): 71-96.

[8] Saeedi, Ali, Miadi Zahra, investigating major obstacles to foreign investment in Iran from the perspective of foreign investors, Economic Journal, Vol. XI, No. II, summer 1390.

[9] Shakeri Abbas, Salimi Feridoun, factors affecting investment in Chabahar free zone and prioritizing them using a mathematical technique AHP, ECONOMIC RESEARCH,Spring 2006; 6 (1 (20)): 95-130.

[10] Abolfazl Mhmoudi, Abdollah., the determinants of foreign investment in Iran, Economic Essays, No. 5, Spring-Summer 2006, pp. 125-89.

[11] Foreign Investment Company, the questions and answers of foreign investors in the Islamic Republic Ayrat / Tehran, time, 1392, 72 pages.

[12] Foreign investment company, investment encouragement guide (with an emphasis on diplomatic measures), Tehran, Rouzegar, 1392, 136 pages.

[13] Salahi, Mahmoud, security of investment ensuringeconomic growth, Aghaz Number 4, August 87, pp. 39-36.

[14] Tahmasebi, Javad., legal barriers to foreign investment in Iran and providing relevant solutions, Mazandaran University, 1390, 124 pages

[15] Fathi Ali, position of improving the business atmosphere to attract foreign investment, economic magazine, numbers 3 and 4, June and July 1392, pages 20-5.

[16] Fotros, MH Emami, M., Factors affecting foreign direct investment in Iran, Economic Journal, monthly economic issues and policies, No. 12, March 1390, pp. 72-53.

[17] Fadzin et al., attracting foreign investment in the infrastructures of trade sector, 2006, Institute of Business Studies and Research, page 433.

[18] Kambozia, Jafar., obstacles to the realization of foreign investment, economic Abrar, Persian date Mordad 13 1381. Page 2.

[19] Mobaser, Darius, structural barriers to foreign investment in Iran, Mellat, 21 July 1380, p. 4.

[20] Mujtahid, Behanm, effects of investment in developing countries, 13 Persian date Dey 1373, p. 12.

[21] Mohebbi, Kaveh, obstacles to the realization of foreign investment, economic Abrar, 27 July 1381, p. 3.

[22] Mohajer, Fatemeh, barriers to foreign investment and bilateral agreements with other countries, Iran, Islamic Azad University, North Tehran Branch, 1389, 183 pages.

[23] Hossein Zadeh Bahrain, Mohammad, government and investment security, the economy world, April 6, 1382, p. 10.

[24] Khaki, G., R. (1378). Research method with an approach to the dissertation writing, Dariat cultur center publications, Tehran, Second Edition 
[25] Khodayari, Hussein, backgrounds and legal obstacles to foreign investment in the Iran / Islamic Azad University, Central Tehran Branch, 1380, 372 pages.

[26] Davousi, Parviz, Shahmorady, Akbar, recognition of the factors affecting foreign direct investment (FDI) in Iran and 46 countries in framework of an integrated model, Journal of Economic Research, No. 20, p. 114.

[27] UNCTAD secretariat in collaboration with the United Nations guidelines on ways to facilitate trade, Tehran, Institute of Business Studies and Research, 1997, 238 pages.

[28] Zulkadir, Malek, Internal political obstacles to attracting foreign direct investment in Iran, Tehran University, 2007, 300 pages.

[29] Rezaei, Mehdi, Factors affecting the absorption of foreign direct investment in the industries of Iran, Tehran, commercial publications, 1388, 249 pages.

[30] Organization of Investment and Economic and Technical Assistance of Iran, desired institutional structure of foreign investment in Iran on the basis of an international comparative study, Tehran, Mahvareh Publishing, 1393, 308 pages.

[31] Naderi, A. Seif Naraqi, M., 1373, human science research methods and how to evaluate it with an emphasis on behavioral sciences, Tehran, Badr publications.

[32] Najarzadeh, Reza., Shaghaghi Shahri, Vahid, Ranking OIC countries based on factors affecting attracting foreign direct investment, Journal of Economic Essays, autumn and winter 2004, Issue 2, pp. 108-87.

[33] Yousefi, Mahdi, 10 indicators of business from the World Bank data view, 19 October 2007, p. 17 and 18.

[34] Abdel Rahman, A.M.M. (2002), "The Determinants of FDI in the Kingdom of Saudi Arabia" Department of Economics, King Saudi University.

[35] Abu Tapanjeh,M.,2008, " Corporate governance from the Islamic prespective: Acomparative analysis with OECD principales", critical prespective on accounting.

[36] Jensen, M. and Meckling, W. 1976. "Theory of the Firm: Managerial Behavior, Agency Costs, and Capital Structure", Journal of Financial Economics, 3, 305 - 360.

[37] Loberman, S. (2002), Trade, FDI and Regional Economic Integration, Cases of North America and Europe, Western Washington University, Collage of Business and Economics Bellingham, Washington, 1998-2225, 37: 1-77.

[38] Ahadi Sarkani. Y, 2006, "Evaluation of the interaction of economic growth with the financial structure and ownership structure", master's thesis, Islamic Azad University, Science and Research branch.

[39] Afshari, A., 2000, Financial management in theory and practice, Volume 1 and 2, Tehran, Soroush Publications. 